\title{
THE SPECIES COMPOSITION AND BIOREGULATORY ACTIVITY OF ENTOMOPHAGES IN POTATO PEST CONTROL SYSTEM
}

\section{I.S. AGAS'EVA, V.Ya. ISMAILOV, M.V. NEFEDOVA, E.V. FEDORENKO}

\author{
All-Russian Research Institute of Biological Plant Protection, Federal Agency of Scientific Organizations, 39, Krasno- \\ dar, 350039 Russia, e-mail dollkaSneba@yandex.ru, vniibzr@mail.kuban.ru \\ Acknowledgements: \\ Supported by Russian Foundation for Basic Research grant № 13-04-96516 and Administration of the Krasnodar Krai \\ Received September 1, 2015
}

\section{Abstract}

Entomophages are considered one of the most important crop pest regulators. Thus, predatory bugs of the subfamily Asopinae - Perillus bioculatus Fabr., Podisus maculiventris Say, Oplomus nigripennis var. pulcher Dull. and parasitic flies Doroforofaga have been introduced to control the Colorado potato beetle (Leptinotarsa decemlineata Say), a super-dominant species, damaging the ground part of potato in several European countries. In this paper, the species composition of the insect fauna of potato cenosis has been studied in Crimea, Slavinsky, Krasnoarmeysky, Dinskoy and Seversky regions of Krasnodar Krai in 2009-2014, as well as population dynamics of injurious and beneficial species populations depending on the abiotic and biotic factors. A total of 35 species belonging to 16 families of 7 insect orders were detected during the study period. Six aphid species (Homoptera, Aphididae) were identified: buckthorn aphid (Aphis nasturtii Kalt.), potato aphid (Aulacorthum solani Kalt.), peach aphid (Myzodes persicae Sulz.), beet or bean aphid (Aphis fabae Scop.), geum aphid (Macrosiphum euphorbiae Thom.), and melon or cotton aphid (Aphis gossypii Glov.). Of six lady bugs species, the Coccinella septempunctata L., Propylea quatuordecimpunctata L. and Harmonia axyridis Pallas were the most frequent. The predatory bugs of Pentatomidae family were the most abundant in the Hemiptera order. The acclimatization of predatory stinkbug populations Perillus bioculatus F. in the South Russia has been determined, that is of major interest for the biological control of the Colorado potato beetle. The synchronous emergency of overwintered stages of Colorado potato beetle, Perillus bioculatus, Zicrona caerulea and other Asopinae predatory bugs was registered. However, small natural population of $P$. bioculatus Fabr. could not always overcome the pest at the beginning of the vegetation, therefore $P$. bioculatus laboratory population was used together with Podisus maculiventris Say population which further control the Colorado potato beetle during the growing season. $P$. maculiventris developed on potato and did not leave solanaceous crops at imago stage continuing to eat Colorado potato beetle and to lay eggs. Due to the optimal feed (eggs of Colorado potato beetle) Perillus number increased to 0.6 insects per bush, and the number of Colorado potato beetle eggs was reduced to 0 . Also, the sensitivity of the entomophages to chemicals and biologicals was studied. Incompatibility of Perillus and Podisus with chemical insecticides was detected, while biological agents Bitoksibatsillin and Fitoverm did not affect the predatory bugs. Thus, since 2008, when $P$. $b i$ oculatus bug acclimatization in Krasnodar region was found, the bug has managed to adapt well to the new environment due to use new feed, and high predatory and migration ability. The study of predatory bug Perillus contributes to L. desemlineata control in South Russia.

Keywords: predatory bugs, entomophages, potato, biological protection

An agricultural ecosystem represents an integral, historically existing biogeocenotic system. Currently, the problems of agricultural ecosystem ecology are as important as the food supply and socioeconomic issues. Plant protection based on biogeocenotic research to reduce the economic costs and the negative effects of pesticides is considered the relevant approach [1-3].

Entomophages are one of the most important crop pest regulators. In agricultural ecosystems, entomophages and entomopathogens perform a unique environment-forming role [4]. Detailed study of agrocoenosis insect species composition is of a great practical importance. The biologically based plant protection against pests and weeds with relatively low costs not only suppresses vital activity of pest species but also prevents their mass reproduction [5]. 
Potato plants, like other solanaceous crops, are unattractive for many Palearctic herbivorous insect species due to the high content of solanine and other alkaloids in ground plant parts. Aphids Aulacorthum solani Kalt., Myzodes persicae Sulz. belong to mass pests that damage the ground part of potato in the European continent in some years, in humid areas especially [6]. In addition to aphids, leafhoppers, the viral disease vectors, are found on solanaceous crops. Epylachna vigintioctomaculata Motsch. damages potato plants seriously in the Primorskii and Khabarovsk regions. Click beetle and cockchafer larvae damage the underground parts of potato. In recent years, the loss from potato moth Phtorimaea operculella Zell. is up to $50 \%$ of crop yield in the south of the country [4].

Colorado potato beetle (Leptinotarsa decemlineata Say) is a superdominant species, damaging the above-ground part of potato; colonization of the Old World with Colorado potato beetle began 100 years ago. The formed potato beetle populations are probably very different from the North American ancestors, since the evolution which took place in the climatic conditions of Eurasia under the constant pressure of pesticides and with the involvement of other selection factors could change the adaptive ability of the pest significantly [7]. In potato fields populated with Colorado potato beetle, a complex of species of polyphagous entomophags attracted by abundant pests and its eggs is found (8).

The possibility of using biological approach in the Colorado potato beetle control was considered by scientists since the beetle has been widely spread in the United States, Canada, and then in Europe [9]. Pathogenic microorganisms were studied and biologicals based on them were developed; entomofauna was studied to identify the most effective predators and parasites; Colorado potato beetle entomophags from the North American continent were introduced.

In some European countries, entomologists introduced predatory stinkbugs Perillus bioculatus Fabr, Podisus maculiventris Say, Oplomus nigripennis var. pulcher Dull. from subfamilies Asopinae, and parasitic flies Doryphorophaga. Extensive experimental data on the biology of introduced predators have been accumulated, and works on their acclimatization in the European territory have been performed [6].

We were the first to study biology and bioregulatory activity of predatory stinkbug Perillus bioculatus Fabr. North American population acclimatized in the Krasnodar. The areas of entomophage acclimatization in the Krasnodar Krai and the Republic of Adygea have been identified, the possibility of effective Colorado potato beetle control by natural populations of predators with the complete cancellation of chemical treatments has been determined, and sensitivity of predatory stinkbugs to the biologicals recommended against Colorado potato beetle has been studied in the field trials.

The objective of this study was to identify the species composition of the major pests and their entomophage complex in potato crops, to study trophic linkages and bioregulatory activity of Colorado potato beetle entomophages, to study the effects of abiotic and biotic factors on the abundance of predatory stinkbugs Perillus bioculatus Fabr. and Podisus maculiventris Say, and to estimate the sensitivity of beneficial insects to pesticides and biologicals used for plant protection.

Technique. Insects were collected in 2009-2014 in the Crimean, Slavyansk, Krasnoarmeisk, Dinskaya, and Seversk regions of the Krasnodar Krai in the crops of potato (Solanum tuberosum L.) varieties Gollandka, Udacha, Lugovskoi, and Avrora using a butterfly net, and Malaise and Mörike traps [10]. Winged aphids were caught and counted according to V.A. Shmyglya [11].

Importance value index was calculated using Fasulaty formula [12]: 


$$
\mathrm{D}=\mathrm{K} \times 100 / \mathrm{K}
$$

where $\mathrm{K}$ is the total count of insect species in all samples, $\mathrm{K}$ is the total count for a particular species, 100 means total importance value indices for all species compared. Insects were taxonomically identified using the keys and entomological collections [13-19].

Stinkbugs Perillus bioculatus Fabr. and Podisus maculiventris Say were reared in controlled conditions at $26 \pm 1{ }^{\circ} \mathrm{C}, 70-75 \%$ air humidity and the daylength of 16 hours. For the mass rearing of predator larvae, we used $30-40 \mathrm{~cm}$ diameter cassettes in which up to 100 adult stinkbugs winged within a day and daily renewed cockchafer larvae were placed. After 10-15 days, young predatory stinkbugs females proceeded to lay eggs. After collecting, the egg clutches were placed into the same cassettes as for adult bugs, 500 eggs per each one. After 5-7 days, the first-stage larvae hatching started, which were fed after molting to the second-stage larvae age $[5,20,21]$.

The observations were performed in 2009-2014 at the experimental plot of All-Russian Research Institute of Biological Plant Protection (VNIIBZR) and at organic farms in the Krasnodar Krai.

The number of Colorado potato beetle (eggs, larvae, and imago) was determined per potato plant by inspecting plants, surface soil and $12 \mathrm{~cm}$-topsoil. The number of Perillus larvae and imago were also counted [22].

Laboratory populations of predatory stinkbugs Perillus and Podisus were outlet in an amount of 1-2 ind. per potato plant. To identify the laboratory Perillus population, insect elytra were labeled with color nitrocellulose enamel prior to letting them out, and further field observations were performed to determine the life expectancy and migration capability of the predator. To prevent migration of predatory bugs, tomato and eggplant plots were located around the potato plots, and summer potato planting was performed.

Summer potato plantations were treated against Colorado potato beetle by Actara (water dispersible granules WDG, $250 \mathrm{~g} / \mathrm{kg}$; Syngenta AG, Switzerland) at a rate of $0.06 \mathrm{~kg} / \mathrm{ha}$. To determine predatory stinkbug sensitivity to the agents, we used Phytoverm (emulsion concentrate EC, 2 g/l; Pharmbiomed, Russia) at a rate of $0.4 \mathrm{l} / \mathrm{ha}$ and Bitoxibacillin (powder $\mathrm{P}$, biological activity BA-1500 AU/mg; Sibbiofarm, Russia) at a rate of $3 \mathrm{~kg} / \mathrm{ha}$. For biologicals application a hydraulic knapsack sprayer was used.

The biological efficacy of the preparation was calculated using a modified Henderson-Tilton's formula (1955) adjusted for the control [12]:

$$
\mathrm{S}=100 \% \times[(\mathrm{Ea} \times \mathrm{Cp}) /(\mathrm{Ep} \times \mathrm{Ca})]
$$

where $\mathrm{S}$ is the number of surviving insects adjusted for control, \%; Ea is the number of insects in the experiment after treatment, ind.; $\mathrm{Cp}$ is the number of insects in the control prior to treatment, ind.; Ep is the number of insects in the experiment prior to treatment, ind.; $\mathrm{Ca}$ is the number of insects in the control after treatment, ind.

For data processing according to common methods [23] we used Statistica 12.6 software (StatSoft Inc., USA).

Results. A total of 35 species belonging to 16 families of 7 insect orders were detected within the study period (Table).

Most species belonged to aphid (Aphididae) and lady bug (Coccinellidae) families (Fig.) (18.2\% each). Six aphid species were identified on potato: buckthorn aphid (Aphis nasturtii Kalt.), potato aphid (Aulacorthum solani Kalt.), peach aphid (Myzodes persicae Sulz.), beet or bean aphid (Aphis fabae Scop.), geum aphid (Macrosiphum euphorbiae Thom.), and melon, or cotton aphid (Aphis gossypii Glov.). A. nasturtii and A. solani were most frequent (53.2-70.1 and 19.9$26.8 \%$ of all species identified, respectively). 
Composition of insect species in potato (Solanum tuberosum L.) cenosis in the Central zone of the Krasnodar Krai (Crimean, Slavyansk, Krasnoarmeisk, Dinskaya, and Seversk regions, 2011-2014)

\begin{tabular}{|c|c|c|}
\hline Name & Specialization & Incidence \\
\hline \multicolumn{3}{|l|}{ Coleopterans order (Coleoptera) } \\
\hline \multicolumn{3}{|l|}{ Soldier beetles family (Cantharididae) } \\
\hline Soldier beetle (Cantharis rustica Fallen, 1807) & $\operatorname{Pr}$ & ++ \\
\hline \multicolumn{3}{|l|}{ Lady bug family (Coccinellidae) } \\
\hline 7-spotted lady bug (Coccinella septempunctata Linnaeus, 1758) & $\operatorname{Pr}$ & ++ \\
\hline Adalia (2-spotted) (Adalia bipunctata Linnaeus, 1758) & $\operatorname{Pr}$ & + \\
\hline 4-spotted lady bug (Harmonia quadripunctata Pontopiddian, 1763) & $\operatorname{Pr}$ & + \\
\hline Asian lady beetle (Harmonia axyridis Pallas, 1773) & $\operatorname{Pr}$ & ++ \\
\hline 14-spotted lady bug (Propylea quatuordecimpunctata Linnaeus, 1758) & $\operatorname{Pr}$ & ++ \\
\hline \multicolumn{3}{|l|}{ 24-spotted lady bug, or psyllobora (Psyllobora vigintiduopunctata Linnaeus, } \\
\hline \multicolumn{3}{|l|}{ Leaf beetles family (Chrysomelidae) } \\
\hline Colorado potato beetle (Leptinotarsa decemlineata Say, 1824) & $\mathrm{Ph}$ & +++ \\
\hline Buckwheat leaf beetle (Gastrophysa polygoni Linnaeus, 1758) & $\mathrm{Ph}$ & + \\
\hline Potato flea beetle (Psylliodes affinis Payk.) & $\mathrm{Ph}$ & + \\
\hline \multicolumn{3}{|l|}{ Order Hemiptera (Hemiptera) } \\
\hline \multicolumn{3}{|l|}{ Berytids family (Berytidae) } \\
\hline Stilt bug (Neides tipularius Linnaeus, 1758) & $\mathrm{Ph}$ & + \\
\hline \multicolumn{3}{|l|}{ Stainers family (Pyrrhocoridae) } \\
\hline Firebug (Pyrrhocoris apterus Linnaeus, 1758) & $\mathrm{Ph} \operatorname{Pr}$ & + \\
\hline \multicolumn{3}{|l|}{ Caspid bugs family (Miridae) } \\
\hline Tarnished plant bug (Lygus rugulipennis Poppius, 1911) & $\mathrm{Ph}$ & ++ \\
\hline \multicolumn{3}{|l|}{ Pentatoma family (Pentatomidae) } \\
\hline Sloe bug (Dolycoris baccarum Linnaeus, 1758) & $\mathrm{Ph}$ & ++ \\
\hline Blue shieldbug (Zicrona caerulea Linnaeus, 1758) & $\operatorname{Pr}$ & ++ \\
\hline Green shield bug (Palomena prasina Linnaeus, 1761) & $\mathrm{Ph}$ & + \\
\hline Double-eyed soldier bug (Perillus bioculatus Fabricius, 1775) & $\operatorname{Pr}$ & ++ \\
\hline \multicolumn{3}{|l|}{ Nabids family (Nabidae) } \\
\hline Damsel bug (Nabis ferus Linnaeus, 1758) & $\operatorname{Pr}$ & + \\
\hline \multicolumn{3}{|l|}{ Homopterans order (Homoptera) } \\
\hline \multicolumn{3}{|l|}{ Leafhoppers family (Cicadellidae) } \\
\hline Plant hopper (Hyalesthes obsoletus Signoret, 1865) & $\mathrm{Ph}$ & ++ \\
\hline Tea-green fly (Empoasca flarescens Fabricius) & $\mathrm{Ph}$ & + \\
\hline Mottled green hopper (Eupteryx atropunctata Goeze, 1778) & $\mathrm{Ph}$ & + \\
\hline \multicolumn{3}{|l|}{ Aphids, true plant lice family (Aphididae) } \\
\hline Buckthorn aphid (Aphis nasturtii Kaltenbach, 1843) & $\mathrm{Ph}$ & +++ \\
\hline Potato aphid (Aulacorthum solani Kaltenbach, 1843) & $\mathrm{Ph}$ & +++ \\
\hline Beet or bean aphid (Aphis fabae Scopoli, 1763) & $\mathrm{Ph}$ & + \\
\hline Melon, or cotton aphid (Aphis gossypii Glover, 1877) & $\mathrm{Ph}$ & + \\
\hline Peach aphid (Myzodes persicae Sulzer, 1776) & $\mathrm{Ph}$ & + \\
\hline Geum aphid (Macrosiphum euphorbiae Thomas, 1878) & $\mathrm{Ph}$ & + \\
\hline \multicolumn{3}{|l|}{ Dipterans order (Diptera) } \\
\hline \multicolumn{3}{|l|}{ Syrphid flies family (Syrphidae) } \\
\hline Banded hoverfly (Syrphus ribesii Linnaeus, 1758) & $\operatorname{Pr}$ & +++ \\
\hline \multicolumn{3}{|l|}{ Tachinid flies family (Tachinidae) } \\
\hline Tachina fly (Ectophasia crassipennis Fabricius, 1794) & $\mathrm{P}$ & + \\
\hline \multicolumn{3}{|l|}{ Order Hymenoptera (Hymenoptera) } \\
\hline Social wasps family (Vespidae) & & \\
\hline Paper wasp (Polistes gallicus Linnaeus, 1767) & $\mathrm{P}$ & + \\
\hline Scelidonid wasps family (Scelionidae) & & \\
\hline Trissolcus vassilievi (Trissolcus vassilievi Mayr, 1913) & $\mathrm{P}$ & ++ \\
\hline Trissolcus grandis (Trissolcus grandis Thomson, 1861) & $\mathrm{P}$ & ++ \\
\hline Ants family (Formicidae) & & \\
\hline Black garden ant (Lasius niger Linnaeus, 1758) & $\operatorname{Pr}$ & ++ \\
\hline Order Neuroptera (Neuroptera, syn. Planipennia) & & \\
\hline Golden-eyed flies family (Chrysopidae) & & \\
\hline Common green lacewing (Chrysoperla carnea Stephens, 1836) & $\operatorname{Pr}$ & + \\
\hline Order Lepidoptera (Lepidoptera) & & \\
\hline Noctuids family (Noctuidae) & & \\
\hline Rosy rustic (Hydraecia micacea Esp.) & $\mathrm{Ph}$ & + \\
\hline
\end{tabular}

Of six lady bugs species, 7-spotted (C. septempunctata L.), 14-spotted (P. quatuordecimpunctata L.) lady bugs, and Asian lady beetle ( $H$. axyridis Pallas) were most frequent. A total of $15.2 \%$ of the species belonged to hemipterans order (Hemiptera), pentatoma family (Pentatomidae) and nabids (Nabidae) fami- 
lies, among which 3 species are predators (Perillus bioculatus Fabr., blue shieldbug Zicrona caerulea L., damsel bug Nabis ferus L.), and 2 species are phytophages (sloe bug Dolycoris baccarum L., Green shield bug Palomena prasina L.). Leafhoppers (Cicadellidae) and leaf beetles (Chrysomelidae) included 3 species each (or $9.1 \%$ each). Ten more families were represented by one species $(3.0 \%)$. Among the species, 18 phytophages and 15 predatory and parasitic insects were identified, representing 54.5 and $45.5 \%$, respectively.

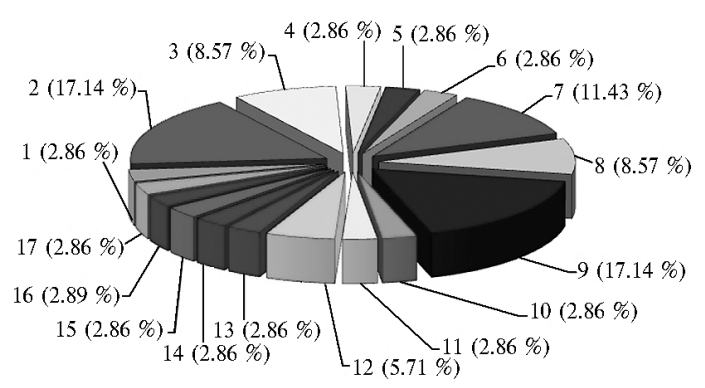

Fractions of insect species from different families in potato cenosis (Solanum tuberosum $L_{\text {.) }}$ in the central zone of Krasnodar Krai: 1 - Soldier beetles ( Cantharidae), 2 - Lady bugs (Coccinellidae), 3 - Leaf beetles (Chrysomelidae), 4 - Berytidae (Berytidae), 5 - Stainers (Pyrrhocoridae), 6 - Caspid bugs (Miridae), 7 - Pentatoma (Pentatomidae), 8 - Leafhoppers (Cicadellidae), 9 - Aphids, true plant lice (Aphididae), 10 - Syrphid flies (Syrphidae), 11 Social wasps (Vespidae), 12 - Scelidonid wasps (Scelionidae), 13 - Ants (Formicidae), 14 - Golden-eyed flies (Chrysopidae), 15 - Noctuids (Noctuidae), 16 - Nabids (Noctuids), 17 - Tachinid flies (Tachinidae) (Crimean, Slavyansk, Krasnoarmeisk, Dinskaya, and Seversk regions, 2011-2014).

In this study, we paid special attention to predatory Asopinae bugs, the controllers of the number of the dominant Colorado potato beetle pest Leptinotarsa decemlineata Say, and primarily to Perillus bioculatus Fabr. acclimatized in the Southern Russia.

Since 1966, P. bioculatus was repeatedly introduced in European countries (Belgium, France, Germany, Italy, Russia, Slovakia, Ukraine, the former Yugoslavia) [2426] for acclimatization and natural regulation of the number of $L$. decemlineata Say, because the pest gained resistance to many pesticides rapidly [27].

Previously (2008, data not shown) during the examination of ragweed thickets (at the territory of VNIIBZR) left on alfalfa field as a reserve for ragweed leaf beetle Zygograma suturalis Fabr., numerous Perillus larvae $\left(10\right.$ to $\left.20 \mathrm{ind} / \mathrm{m}^{2}\right)$ were found which were actively eating herbiphages. Interestingly, the predator had obviously self-acclimated, spread within the agroecosystems of the South of Russia, and could be used to control herbiphages. At the natural predator habitat redistribution to neighboring potato crops, the Perillus to Colorado potato beetle ratio of 1:9-1:15 (up to 10 egg clutches and 10-15 larvae per plant) appeared to be sufficient for pest elimination. In this, ragweed leaf beetle is a feed source for predatory stinkbug, the environmental and economic role of the latter being much greater. Comparing Perillus and Podisus activity against Colorado potato beetle, we demonstrated that, despite the higher aggressiveness of Podisus larvae, it is inferior to Perillus in the prolonged effect: $P$. maculiventris, like most Asopinae bugs, prefers shrub-arboreal habitats, and leaves potato crops upon reaching the imaginal stage, while $P$. bioculatus continues to eat, lay eggs and reproduce. Later (starting from 2009), we studied the habitat distribution patterns of predatory Asopinae bugs in solanaceous cenoses, and the factors necessary for activation and reproduction of $P$. bioculatus under natural conditions.

To assess Perillus feed supply, simultaneous censuring of the bug and its victims (Colorado potato beetle and ragweed leaf beetle) was conducted and its leading role in the entomophage population dynamics was defined. The reduced number of these herbiphages at VNIIBZR fields resulted in a significant decrease in the density of $P$. bioculatus population: in $2008-2009$, it reached $20-30 \mathrm{ind} / \mathrm{m}^{2}$, and just single individuals [20] were reported in 2011-2014. The control by 
enthomophages was another important factor. Over the years, Perillus eggs (5-28 \%) were infected with parasite-oviphages Trissolcus vassilievi Mayr and Trissolcus grandis (Hymenoptera: Scelionidae), and imago (8-15\%) were infected with Phasiinae flies (subfamily Phasiinae, family Tachinidae).

Regarding the timing of Perillus, ragweed leaf beetle, and Colorado potato beetle development, in 2010, due to the cold spring, the first ragweed leaf beetle individuals appeared in the last ten days of April, overwintered Perillus stinkbugs were found in early May, and the first overwintered Colorado potato beetles were found at the same time. Perillus was represented by the red phenoform only. Other phenoforms appeared in early June, when the temperature has stabilized. Colorado potato beetle egg clutches were the most preferred feed for Perillus, but it actively fed on larvae and imago as well. In 2013, favorable conditions for Perillus hibernation (early and warm spring) made it possible to synchronize the development cycles of predatory stinkbug and Colorado potato beetle. The biological efficacy of the natural regulation of the number of the first pest generation reached 95-99\% at the experimental plot. Only one clutch of the 54 recorded ones has not been destroyed by the predator. That is, the earliest developmental stage of Colorado potato beetle (egg stage) was suppressed, and the development of the harming stage (the larva) did not take place.

In 2014, the appearance of Perillus was recorded on May 3 (simultaneously with the overwintered generation of Colorado potato beetle). Due to warm spring (the temperatures in the first decade of May exceeded the long-term average value by $2.3^{\circ} \mathrm{C}$ ), the conditions were favorable for Colorado potato beetle reproduction, and its number exceeded the economic harmfulness level (EHL) greatly. The number of the natural Perillus population was low and not sufficient to control the pest, and the additionally used laboratory Perillus population manifested its activity: the insects reduced the number of the Colorado potato beetle effectively, mated, and laid eggs. Perillus did not leave the habitat for about 1 month (single laboratory population individuals were observed for 40 days from the date of introduction). In other words, during this time, laboratory Perillus population will stay at the protected area in the presence of feed (Colorado potato beetle) and the absence of chemical treatments. The laboratory population provided a prolonged protective effect due to the emergence of the second generations of laboratory and natural predator populations.

At the beginning of the third decade of May, the number of Colorado potato beetle imago and egg clutches was about 0.3 per plant with Perillus counts 0.4 per plant in the natural population. Due to the optimum feed supply (Colorado potato beetle eggs), the number of Perillus increased to 0.6 per plant, and the number of Colorado potato beetle eggs reduced to 0 by the end of May. This value was maintained until the third decade of June. A few new clutches of eggs (only drunk ones found), Colorado potato beetle imago and larvae were the feed for Perillus in this time, and the number of Colorado potato beetle declined steadily to 0.07 per plant by mid-July.

The plots of summer planted potato where chemical treatments with Actara preparation were applied were located at a distance of 20-25 meters from the area of biological control. The treatment restrained the number of Colorado potato beetle by $95-98 \%$ and resulted in an almost complete destruction of the natural Perillus population. In 2 weeks after treatment with this preparation, the pest re-colonized potato with imago counts of 0.3 ind/plant, and he number of egg clutches of 0.1-0.4 per plant.

The emergence of egg clutches on late potato planting provided feed supply for Perillus. At the same time, a decreased number of Perillus was observed on the spring planting which was due to the progressive elimination of the 
feed resource (all Colorado potato beetle preimaginal stages).

For the integration of biological crop protection products, we studied predatory stinkbug sensitivity to biologicals. Phytoverm was low toxic for Podisus larvae and older ages (deaths did not exceed $15 \%$ ), and intermediately toxic for the larvae of younger ages (deaths made up 47-60\%). Bitoxibacillin at a rate of $3 \mathrm{~kg} / \mathrm{ha}$ did not have toxic effects on Perillus imago and the majority of preimaginal stages, except the larvae of younger ages, the deaths of which was about $50 \%$ at the Bitoxibacillin rate of $1.5 \mathrm{~kg} / \mathrm{ha}$.

These results suggest that the efficacy of biological protection of potato can be improved by synchronizing Colorado potato beetle and Perillus phenology. This is achieved by later potato planting and additional introduction of predatory stinkbugs or treatment with the biologicals which do not reduce entomophage effectiveness.

Observations over the Podisus laboratory population in the field at the plot of spring potato planting demonstrated active reduction of the pest population by the predator. As a result, new data on the predator migration and the duration of Podisus staying at the experimental plot were obtained. We succeeded to determine that feed supply is the decisive factor in the rate and distance of Podisus larvae migration which is confirmed by the experiments performed by N.A. Filippov et al. [28]. Podisus spread over the entire plot area evenly and stayed there after winging, which was observed for the first time for many years of research: after imaginal molt, predator usually left potato (probably, as mentioned previously, due to the preferences of tree and shrub habitat). Podisus hygrophylity has been noted in publications repeatedly [29]. The tendency to stay in wetted areas irrespective of the presence of feed [6] and the predominant importance of positive hydrotaxis in selecting preferred conditions [30, 31] has been described in this species. In our experiments performed in June and July 2014, when Podisus reached the imago stage, the rainfall actually exceeded the average value for many years.

In 2014, new geographic populations of Perillus were found in UstLabinsk and Abinsk regions of the Krasnodar Krai. Geographic populations of Perillus identified in some areas of Kuban, Adygeya, and Rostov region earlier $[19,20,32]$ and the reports on the detection of the predator in Moldova, Ukraine [33-35], Bulgaria [36], Greece [37], Turkey [37-39], Serbia [40], and India [41] lead to the assumption of the entomophage acclimatization in the vast territory of Eurasia.

Thus, we have studied the species composition of the insect fauna of potato plants in the Krasnodar Krai and found the defining role of entomophages in biocenotic control of the number of phytophages. Since 2008, when the phenomenon of stinkbug Perillus bioculatus acclimatization in the Krasnodar Krai has been defined, it managed to adapt well to the environment due to new feed sources used, high predatory and migration capacity. Feed supply and parasitic activity of Scelidonidae wasps and Phasiinae flies were the main biotic factors affecting the number of Perillus. At low pest population at the beginning of the growing season, protection of potato by the natural population predatory stinkbug Rerillus is possible. If the pest population exceeds the economic harmfulness level, treatment with Phytoverm and Bitoxibacillin compatible with entomophages, or additional introduction of artificially propagated predatory stinkbugs are required. Studying natural reserves of predatory stinkbug Perillus is promising for the development of the approaches for Colorado potato beetle Leptinotarsa desemlineata control in the Krasnodar Krai and the South of Russia. Effectiveness of biological control of Colorado beetle with complete cancellation of chemical treatments for plant protection has been proven at a number of 


\section{REFEREN C ES}

1. Khak i mov F.R. Osobennosti ekologii zhukov bozh'ikh korovok (Coleoptera, Coccinellidae) v usloviyakh oroshaemykh zemel' Gissarskoi doliny Tadzhikistana. Avtoreferat kandidatskoi dissertatsii [Features of beetle ladybirds (Coleoptera, Coccinellidae) ecology in the irrigated Hissar valleys of Tajikistan. PhD Thesis]. Dushanbe, 2011 (in Russ.).

2. Ratnadass A., Fernandes P., Avelino J., Habib R. Plant species diversity for sustainable management of crop pests and diseases in agroecosystems: a review. Agronomy for Sustainable Development, 2012, 32(1): 273-303 (doi: 10.1007/s13593-011-0022-4).

3. Chagnon M., Kreutzweiser D., Mitchell E.A.D., Morrissey C.A., Noome D.A., Van der S luijs J.P. Risks of large-scale use of systemic insecticides to ecosystem functioning and services. Environmental Science and Pollution Research, 2015, 22(1): 119-134 (doi: 10.1007/s11356-014-3277-x).

4. Is mailov V.YA., Ag a s'e va I.S., Fedore n ko E.V., N e fedova M.V. Nauka Kubani, 2014, 1: 36-39 (in Russ.).

5. Zlotin A.Z. Tekhnicheskaya entomologiya. Spravochnoe posobie [Technical entomology: a reference guide]. Kiev, 1989 (in Russ.).

6. Gu s e v G.V. Entomofagi koloradskogo zhuka [The entomophages of Colorado potato beetle]. Moscow, 1991 (in Russ.).

7. Kol a r C.S., Lo dg e D.M. Progress in invasion biology: predicting invaders. Trends in Ecology \& Evolution, 2001, 16: 199-204.

8. Gus ev G.V., Kova 1' A.G. Biologicheskii metod bor'by s koloradskim zhukom (Prilozhenie $k$ zhurnalu "Zashchita rastenii») [Biocontrol of Colorado potato beetle (Supplement to the Plant Protection journal)]. Moscow, 1990 (in Russ.).

9. D e C le r c q P. Dark clouds and their silvei linings: Exolic generalist predators in augmentative biological control. Neotropical Entomology, 2002, 31(2): 169-176.

10. Kovale nkov V.G., T y u rin a N.M. Agro XXI, 2000, 3: 8-9 (in Russ.).

11. S h m y gly a V.A. Kratkoe metodicheskoe posobie po uchetu tlei na posadkakh kartofelya [Brief handbook on accounting aphids on potato crop]. Moscow, 1969 (in Russ.).

12. Metodicheskie ukazaniya po registratsionnym ispytaniyam insektitsidov, akaritsidov, mollyuskotsidov $i$ rodentitsidov v sel'skom khozyaistve /Pod redaktsiei V.I. Dolzhenko [Guidelines for the registration tests of insecticides, miticides, molluscicides and rodenticides in agriculture. V.I. Dolzhenko (ed.)]. St. Petersburg, 2009 (in Russ.).

13. Opredelitel' nasekomykh Dal'nego Vostoka SSSR. Tom 2. Ravnokrylye i poluzhestkokrylye [Insects of Far East of the USSR: systematic manual. V. 2. Homoptera and Hemiptera]. Leningrad, 1988 (in Russ.).

14. Opredelitel' nasekomykh Dal'nego Vostoka SSSR. Tom 3. Zhestkokrylye, ili Zhuki. Chast' 1 [Insects of Far East of the USSR: systematic manual. V. 3. Coleoptera. P. 1]. Leningrad, 1989 (in Russ.).

15. Opredelitel' nasekomykh Dal'nego Vostoka SSSR. Tom 3. Zhestkokrylye, ili Zhuki. Chast' 2 [Insects of Far East of the USSR: systematic manual. V. 3. Coleoptera. P. 2]. St. Petersburg, 1992 (in Russ.).

16. Opredelitel' nasekomykh Dal'nego Vostoka Rossii. Tom 4. Setchatokryloobraznye, skorpionnitsy, pereponchatokrylye [Insects of the Russian Far East: systematic manual. V. 4. Neuroptera, Mecoptera, Hymenoptera]. St. Petersburg, 1995 (in Russ.).

17. Opredelitel' nasekomykh Dal'nego Vostoka Rossii. Tom 5. Rucheiniki i cheshuekrylye. Chast' 1-3 [Insects of the Russian Far East: systematic manual. V. 5. Trichoptera and Lepidoptera. P. 1-3]. Vladivostok, 2001 (in Russ.).

18. Opredelitel' nasekomykh Dal'nego Vostoka Rossii. Tom 6. Dvukrylye i blokhi. Chast' 1, 2 [Insects of the Russian Far East: systematic manual. V. 6. Diptera and Siphonaptera. P. 1, 2]. Vladivostok, 1999 (in Russ.).

19. I s m a i lo v V.Ya., Ag a s'e va I.S. Zashchita i karantin rastenii, 2010, 2: 30-31 (in Russ.).

20. Agas'eva I.S., I s mailov V.Ya., Fedorenko E.V., Nefedova M.V. Zashchita $i$ karantin rastenii, 2013, 11: 21-23 (in Russ.).

21. Ta m a ri n a N.A. Tekhnicheskaya entomologiya [Technical entomology]. Moscow, 1987 (in Russ.).

22. Voronin K.E., Pukinskaya G.A., Novozhilov K.V. et al. Metodicheskie ukazaniya po ispol'zovaniyu kriteriev effektivnosti prirodnykh populyatsii entomofagov $i$ entomopatogenov /Pod redaktsiei K.V. Novozhilova [Guidelines on the use of performance criteria in natural populations of entomophags and entomopathogens. K.V. Novozhilov (ed.)]. Moscow, 1991 (in Russ.).

23. Dospekhov B.A. Metodika polevogo opyta [Methods in field trials]. Moscow, 1985 (in Russ.).

24. Rabits ch W. True Bugs (Hemiptera, Heteroptera). Chapter 9.1. BioRisk, 2010, 4: 407-403 (doi: 10.3897/biorisk.4.44).

25. D e C le r c q P. Predaceous stinkbugs (Pentatomidae:Asopinae). In: Heteroptera of economic importance. C.W. Schaefer, A.R. Panizzi (eds.). Boca Raton, Florida, 2000: 737-789.

26. Rabits ch W. Alien true bugs of Europe (Insecta: Hemiptera:Heteroptera). Zootaxa, 2008, 1827: 1-44. 
27. W e g o r e k P. Insecticide resistance management strategy for Colorado Potato Beetle (Leptinotarsa decemlineata Say) in Poland. Resistant Pest Management Newsletter, 2002, 11(2): 22-30.

28. Filippov N.A., Vorotyntseva A.F., Stengach A.S., Tuzlukov A.V. V sbornike: Entomofagi $i$ mikroorganizmy $v$ zashchite rastenii [In: Entomophages and microorganisma in plant protection]. Kishinev, 1987: 43-47 (in Russ.).

29. I z h e v s k i i S.S., Z is k i n d L.A. V sbornike: Biologicheskoe podavlenie karantinnykh vreditelei $i$ sornyakov [In: Biocontrol of quarantine pests and weeds]. Moscow, 1981: 20-37 (in Russ.).

30. C o uturie r A. Contribution à l'étude biologique de Podisus maculiventris Say, prédateur américain du Doryphore. Ann. Epiphyt. Phytogen., 1938, 4(1): 95-165.

31. $\mathrm{Nu} \mathrm{m}$ at a $\mathrm{H}$. Environmental factors that determine the seasonal onset and termination of reproduction in seed-sucking bugs (Heteroptera) in Japan. Appl. Ent. Zool., 2004, 39(4): 565-573 (doi: 10.1303/aez.2004.565).

32. Artok hin K.S., Ig n t o va P.K., T e rskov E.N. Kavkazskii entomologicheskii byulleten', 2012, 8(2): 199-202 (in Russ.).

33. Elisovetskaya D.S., Derzhanski i V.V. Materialy Mezhdunarodnoi nauchno-prakticheskoi konferentsii «Biologicheskaya zashchita rastenii - osnova stabilizatsii agroekosistem» [Proc. Int. Conf. «Biocontrol as basic approach to agro ecosystem stabilization»]. Krasnodar, 2014, 8: 145-151 (in Russ.).

34. Derjanschi V., Eli is oveţcaia D., Calestru L. Ploşniţa Perillus bioculatus F. (Heteroptera, Pentatomidae) - prăd torul principal al gândacului de Colorado. Akademos, 2013, 4(31): 90-93.

35. De rja ns ch i V., E lis o ve țc a i a D. Predatory shield bug Perillus bioculatus F. (Hemiptera, Pentatomidae) in the Republic of Moldova: acclimatization or natural colonization? $M a-$ ter. Intern. Conf. of Zooloists «Actual problems of protection and sustainable use of the animal world diversity». Chisinau, 2013, Issue 8: 124-125.

36. Simov N., Langourov M., Grozeva S., Gradinarov D. New and interesting records of alien and native true bugs (Hemiptera:Heteroptera) from Bulgaria. Acta zoologica bulgarica, 2012, 3(64): 241-252.

37. Kiva n M. Some observations on Perillus bioculatus (F.) (Heteroptera:Pentatomidae) a new record for the entomofauna of Turkey. Türkish Journal of Entomology, 2004, 28(2): 95-98.

38. Onder F., Karsavuran Y., T e z c a n S., F e n t M. Heteroptera (Insecta) catalogue of Turkey. Meta Basým Matbaacýlýk Hizmetleri, Ýzmir, 2006.

39. Fent M., Akt a ç N. Die Verbreitung des Perillus bioculatus (Fab.) (Heteroptera:Pentatomidae:Asopinae) im türkischen Teil Thrakiens. Heteropteron, 2007, 25: 7-10.

40. Proti L.J., Ži vi N. Perillus bioculatus (Fabricius) (Heteroptera:Pentatomidae) in Serbia. Acta entomologica serbica, 2012, 17(1/2): 23-28.

41. Pras ad C.S., Pal Ris hi. First record of two spotted stink bug, Perillus bioculatus (Fab.) from Meerut (U.P.) North India. International Journal of Environmental \& Agriculture Research (IJOEAR), 2015, 1(3): 9-11. 